\title{
PENGARUH VARIASI BEBAN TERHADAP EFISIENSI SOLAR CELL DENGAN KAPASITAS 50 WP
}

\author{
Rusman \\ Staf Pengajar Jurusan Kemaritiman Politeknik Negeri Samarinda \\ Jl. Kapal Selam 1 No. 10 RT. 17 Loktuan Bontang \\ rusman@polnes.ac.id
}

\begin{abstract}
Abstrak
Efek krisis energi di Indonesia masih sangat dirasakan oleh masyarakat Indonesia. Energi listrik menjadi kebutuhan yang sangat penting bagi masyarakat, sejalan dengan meningkatnya laju pertumbuhan penduduk dan pembangunan di segala bidang. Sebagai upaya untuk memenuhi kebutuhan tenaga listrik tersebut sekaligus penanggulangan kondisi krisis penyediaan tenaga listrik di beberapa daerah, maka dapat memanfaatkan Potensi alam untuk dijadikan energi listrik. Salah satu Potensi alam sebagai sumber energi listrik adalah energi tenaga matahari. Matahari merupakan sumber energi utama bagi sebagian besar proses-proses yang terjadi dipermukaan bumi. Tujuan penelitian ini akan menghasilkan efisiensi solar cell dengan metode penelitian yang menggunakan beberapa beban yaitu 3 watt, 6 watt dan 9 watt dalam mempengaruhi efisiensi solar cell. Efisiensi dengan menggunakan waktu pengambilan data dari jam 08.00 sampai dengan 17.00. Hasil yang didapatkan yaitu untuk beban 3 watt yaitu menghasilkan efisiensi $84 \%$ dan untuk beban 6 watt yaitu menghasilkan efisiensi $90 \%$ serta beban 9 watt menghasilkan menghasilkan efisiensi $86 \%$ sehingga disimpulkan bahwa efisiensi solar cell dengan kapasitas 50 WP maksimum pada jam 12.00 siang.
\end{abstract}

Kata Kunci: solar cell, efisiensi, kinerja, tenaga surya.

\section{Pendahuluan}

Efek krisis energi di Indonesia masih sangat dirasakan oleh masyarakat QIndo-nesid. Energi listrik menjadi kebutuhan yang sangat penting bagi masyarakat, seja-lan dengan meningkatnya laju pertumbuhan penduduk dan pembangunan di segala bidang. Untuk dapat memenuhi kebutuhan akan listrik yang semakin pesat tersebut, maka pemerintah terus meningkatkan program pembangunan prasarana dan sarana tenaga listrik untuk menjangkau wilayah-wilayah yang ada di Indonesia. Akan tetapi, kondisi negara Indonesia adalah negara yang sangat luas dan terdiri dari beribu-ribu pulau dan dengan penyebaran penduduk yang tidak merata serta masih banyak daerah-daerah yang terpencil yang menjadikan kendala utama untuk melakukan pendistribusian pembangkit listrik ke setiap pelosok-pelosok negeri kita ini. Maka wajar kalau kita masih banyak menjumpai masyarakat di pedesaan, pesisir pantai dan daerah pegunungan yang belum merasakan penerangan listrik dan tidak terjangkau oleh pembangkit listrik negara (PLN).

Sebagai upaya untuk memenuhi kebutuhan tenaga listrik tersebut sekaligus penanggulangan kondisi krisis penyediaan tenaga listrik di beberapa daerah, maka dapat memanfaatkan Potensi alam untuk dijadikan energi listrik. Salah satu Potensi alam sebagai sumber energi listrik adalah energi tenaga matahari. Matahari merupakan sum-ber energi utama bagi sebagian besar pro-ses-proses yang terjadi dipermukaan bumi. Radiasi matahari yang diterima permukaan bumi merupakan masukan fundamental untuk banyak aspek terutama merupakan parameter penting dalam aplikasi solar sel sebagi pembangkit listrik. sel matahari merupakan piranti yang dapat mengkonversi cahaya matahari menjadi energi listrik. Energi matahari dapat menghasilkan daya hingga $156.486 \mathrm{MW}$, jumlah yang lebih besar jika dibandingkan dengan sum-ber energi terbarukan yang lainnya. Indo-nesia merupakan negara yang terletak da-lam jalur khatulistiwa yang sepanjang ta-hun mendapatkan cahaya 
matahari yang berlimpah dengan intensitas radiasi mata-hari rata-rata sekitar $4.8 \mathrm{kWh} / \mathrm{m}^{2}$ per hari di seluruh wilayah Indonesia. Pemanfaatan energi matahari sebagai pembangkit listrik tenaga surya (PLTS) sangat diminati dan mulai dikembangkan diseluruh pelosok negeri dengan melakukan banyak sekali penelitian serta pengujian.

Bagaimana kinerja solar cell dengan variasi beban yang diberikan dengan kapasitas 50 WP.?

\section{Tinjauan Pustaka}

Sang surya atau matahari meru-pakan bintang yang istimewa dan me-mpunyai radius sejauh $6,96 \times 10^{5} \mathrm{~km}$ dan terletak sejauh $1,496 \times 10^{5} \mathrm{~km}$ dari bumi. Besar jumlah energi yang dikeluarkan oleh matahari sukar dibayangkan. Menurut salah satu perkiraan, inti sang surya merupakan suatu tungku termonuklir bersuhu 100 juta derajat celcius setiap detik mengonversi 5 tonne materi menjadi energi yang dipan-carkan ke angkasa luas sebanyak $6,41 \times 10^{7} \mathrm{~W} / \mathrm{m}^{2}$.

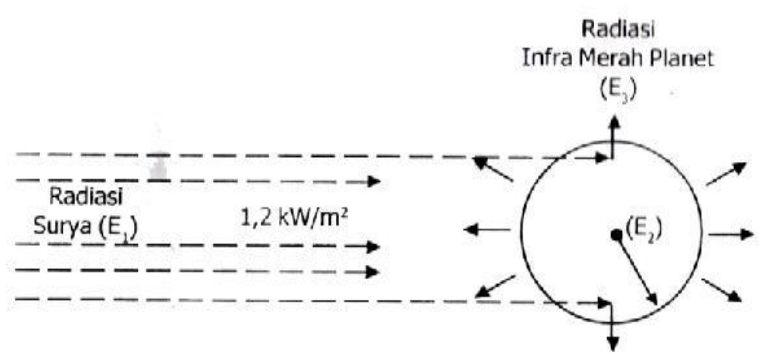

\section{Gambar 1. Radiasi Matahari}

\section{Radiasi Energi Matahari}

Energi Matahari merupakan sumber energi utama untuk proses-proses yang terjadi di Bumi. Energi matahari sangat membantu berbagai proses fisis dan biologis di Bumi. Radiasi adalah suatu proses perambatan energi (panas) dalam bentuk gelombang elektromagnetik yang tanpa memerlukan zat perantara.

Energi Matahari bisa sampai ke permukaan Bumi adalah dengan cara radiasi (pancaran), karena diantara Bumi dan Matahari terdapat ruang hampa (tidak ada zat perantara), sedangkan gelombang elektromagnetik adalah suatu bentuk gelombang yang dirambatkan dalam bentuk komponen medan listrik dan medan magnet, sehingga dapat merambat dengan kecepatan yang sangat tinggi dan tanpa memerlukan zat atau medium perantara.

Dari sekian banyak energi yang dikeluarkan matahari yang sampai ke Bumi melalui melalui proses perambatan tadi kemudian diserap oleh Bumi. Energi yang diserap ini akan menyebabkan suhu dari Bumi akan naik. Pada gilirannya, suhu Bumi yang hangat atau panas ini akan memancarkan juga sebagian energinya, sehingga energi yang diterima Bumi = energi yang diserap Bumi + energi yang dipancarkan Bumi.

Pembangkit Listrik Tenaga Surya (PLTS) pada dasarnya adalah pecatu daya (alat yang menyediakan daya), dan dapat dirancang untuk mencatu kebutuhan listrik yang kecil sampai dengan besar, baik secara mandiri, maupun dengan hybrid (dikombinasikan dengan sumber energi lain) baik dengan metode Desentralisasi (satu rumah satu pembangkit) maupun dengan metode Sentralisasi (listrik didistribusikan dengan jaringan kabel).

Pada siang hari modul surya/panel solar cell menerima cahaya matahari yang kemudian diubah menjadi listrik melalui proses photovoltaic. Energi listrik yang dihasilkan oleh modul surya dapat langsung disalurkan ke beban atau disimpan dalam baterai sebelum digunakan ke beban. Dan arus searah DC (direct current) yang dihasilkan dari modul surya yang telah tersimpan dalam baterai sebelum digunakan ke beban terlebih dahulu.

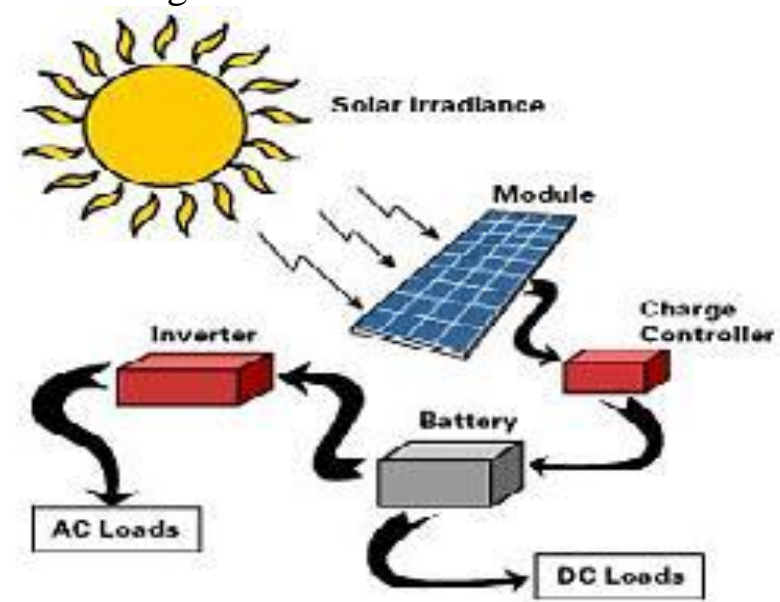

Gambar 2. Konsep kerja sell surya [1].

Modul ini berfungsi merubah cahaya matahari menjadi listrik arus searah (DC). Listrik tenaga matahari dibangkitkan oleh komponen yang disebut solar cell, kom-ponen ini mengkonversi energi matahari menjadi 
energi listrik. Solar cell meru-pakan komponen vital yang terbuat dari bahan semi konduktor. Tenaga listrik dihasilkan oleh satu solar cell sangat kecil, maka beberapa solar cell harus digabung sehingga terbentuklah satuan komponen yang disebut module. Pada aplikasinya karena tenaga listrik yang dihasilkan oleh module ini masih kecil, maka dalam pemanfaatannya beberapa modul digabung-kan sehingga terbentuklah apa yang disebut array. Perhatikan Gambar berikut ini.

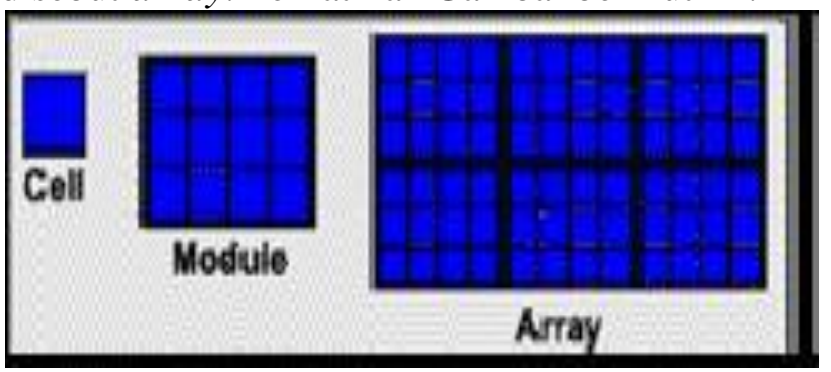

Gambar 3. Panel Sel Surya [2]

Sel surya atau photovoltaic adalah perangkat yang mengkonversi radiasi sinar matahari menjadi energi listrik. Efek photovoltaic ini ditemukan oleh Becquerel pada tahun 1839, dimana Becquerel mendeteksi adanya tegangan foto ketika sinar matahari mengenai elektroda pada larutan elektrolit. Pada tahun 1954 peneliti menemukan untuk pertama kali sel surya silikon berbasis p$\mathrm{n}$ junction dengan efisiensi 6\%. Sekarang ini, sel surya silikon mendominasi pasar sel surya dengan pangsa pasar sekitar $82 \%$ dan efisiensi lab dan komersil berturut-turut yaitu $24,7 \%$ dan $15 \%$.

Kepingan sel photovoltaic terdiri atas kristal silikon yang memiliki dua lapisan silisium doped, yaitu lapisan sel surya yang menghadap ke cahaya mata-hari memiliki doped negatif dengan lapisan fosfor, sementara lapisan di bawahnya terdiri dari doped positif dengan lapisan borium. Antara kedua la-pisan dibatasi oleh penghubung p-n. Jika pada per-mukaan sel photovoltaic terkena cahaya matahari maka pada sel bagian atas akan terbentuk muatan-muatan negatif yang bersatu pada lapisan fosfor. Sedangkan pada bagian bawah lapisan sel photovoltaic akan membentuk muatan positif pada lapisan borium.

Kedua permukaan tersebut akan saling mengerucut muatan masing- masing-nya jika sel photovoltaic terkena sinar matahari. Sehingga pada kedua sisi sel photovoltaic akan menghasilkan beda potensial berupa tegangan listrik. Jika kedua sisnya dihubungkan dengan beban berupa lampu menyebabkan lampu akan menyala. Suatu kristal silikon tunggal photovoltaic dengan luas permukaan $100 \mathrm{~cm} 2$ akan menghasilkan sekitar 1,5 W dengan tegangan sekitar $0,5 \mathrm{~V}$ tegangan searah (0,5 V-DC) dan arus sekitar $2 \mathrm{~A}$ di bawah cahaya matahari dengan panas penuh (intensitas sekitar 1000W/m2)[3]. Perhatikan gambar berikut.

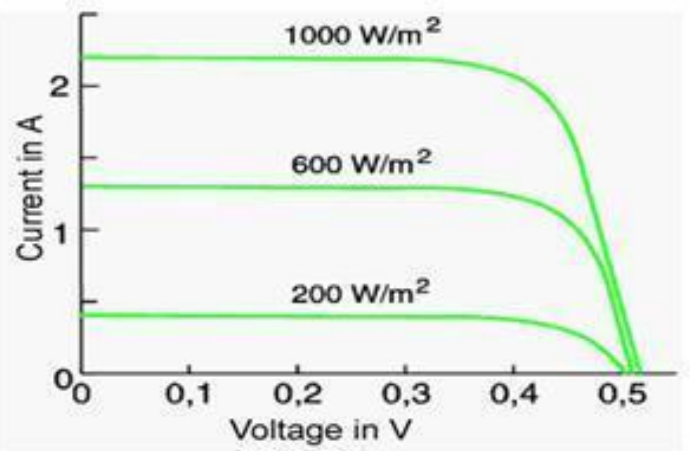

Gambar 4 Karakteristik Sel Photovoltaic[2]

Charge controller berfungsi meng-atur lalu lintas listrik dari modul surya ke baterai. Alat ini juga memiliki banyak fungsi yang pada dasarnya ditujukan untuk melindungi baterai. Pengisi baterai atau charge controlleradalah peralatan elek-tronik yang digunakan untuk mengatur arus searah DC yang diisi ke baterai dan diambil dari baterai ke beban. Charge controller mengatur overcharging (kelebihan pengi-sian karena baterai sudah penuh) dan kelebihan tegangan (overvoltage) dari panel surya. Kelebihan tegangan dan pengisian akan mengurangi umur baterai. Charge controller menerapkan teknologi Pulse Width Modulation (PWM) untuk mengatur fungsi pengisian baterai dan pembebasan arus dari baterai ke beban. Panel surya $12 \mathrm{~V}$ umumnya memiliki tegangan output $16-21 \mathrm{~V}$. Jadi tanpa charge controller, baterai akan rusak oleh overcharging dan ketidakstabilan tegangan. Baterai umumnya di-charge pada tegangan 1414,7 V. Fungsi detail dari charge controller antara lain:

a. Mengatur arus untuk pengisian ke baterai, menghindari overcharging, dan overvoltage. Apabila baterai dalam keadaan kondisi sudah terisi penuh maka listrik 
yang disuplai dari modul surya tidak akan dimasukan lagi pada baterai dan sebaliknya juga jika keadaan kondisi baterai sudah kurang dari 30\% maka charge controller tersebut akan mengisi kembali baterai sampai penuh. Proses pengisian baterai dan modul surya tersebut melalui charge controller akan terus berulang secara otomatis (smart charging) selama energi surya masih cukup untuk bias diproses oleh modul surya (selama matahari terang benderang). Charge controller juga ber-fungsi melindungi baterai ketika sedang mengalami proses pengisian dari modul surya untuk menghindari arus berlebih dari proses pengisian tersebut, yang akan menyebabkan kerusakan pada baterai. Sehingga dengan cara tersebut baterai dalam pemakaiannya memiliki usia yang lebih lama.

b. Mengatur arus yang dibebaskan atau diambil dari baterai agar baterai tidak full discharge dan overloading.

c. Monitoring temperatur baterai

Charge controller biasanya terdiri dari satu input (dua terminal) yang terhubung dengan output panel sel surya, satu output (dua terminal) yang terhubung dengan baterai/aki dan satu output (dua terminal) yang terhubung dengan beban. Arus listrik DC yang berasal dari baterai tidak mungkin masuk ke panel surya karena biasanya ada dioda proteksi yang hanya melewatkan arus listrik DC dari panel surya ke baterai, bukan sebaliknya. Adapun dua jenis teknologi charge controller yang digunakan, yaitu :

PWM (Pulse Wide Modulation), seperti namanya menggunakan lebar pulse dari on dan off electrical, sehingga menciptakan seakanakan sine wave electrical form.

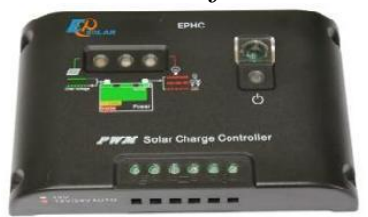

Gambar 5. Charge Controller tipe PWM[2]

MPPT (Maximun Power Point Trac-ker), yang lebih efisien konversi DC to DC (Direct Current). MPPT dapat mengambil daya maksimum dari panel surya. MPPT charge controller dapat menyimpan kelebihan daya yang tidak digunakan oleh beban ke dalam baterai, dan apabila daya yang dibutuhkan beban lebih besar dari daya yang dihasilkan oleh panel surya, maka daya dapat diambil dari baterai.

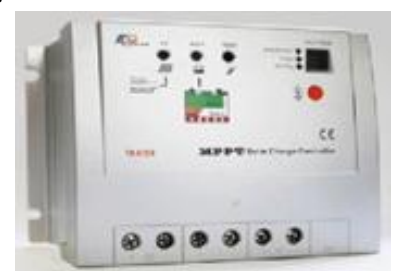

Gambar 6. Charge Controller tipe MPPT[2]

Contoh dari kelebihan MPPT ada-lah panel surya ukuran $120 \mathrm{~W}$, memiliki karakteristik Maximun Power Voltage 17,1 V dan Maximun Power Current 7,02 A. Dengan charge controller selain MPPT dan tegangan baterai $12,4 \mathrm{~V}$ berarti daya yang dihasilkan adalah $12,4 \mathrm{~V}$ x 7,02 A $=87,05 \mathrm{~W}$. Dengan MPPT, arus yang bisa diberikan adalah sekitar $120 \mathrm{~W}: 12,4 \mathrm{~V}=9,68 \mathrm{~A}$.

\section{Baterai (Battery/Accumulator)}

Baterai pada PLTS berfungsi untuk menyimpan arus listrik yang dihasilkan oleh panel surya sebelum dimanfaatkan untuk mengoperasikan beban. Beban dapat berupa lampu refrigerator atau peralatan elektronik dan peralatan lainnya yang membutuhkan listrik DC.

Accumulator atau yang akrab disebut accu/aki adalah salah satu komponen penting pada kendaraan bermotor. Selain berfungsi untuk menggerakkan motor sta-rter, aki juga berperan sebagai penyimpan listrik dan sekaligus sebagai penstabil tegangan dan arus listrik kendaraan.

Menurut Syam Hardi akumulator ini berasal dari bahasa asing yaitu: accu (mulator) = baterij (Belanda), accumulator = storange battery (Inggris), akkumulator = bleibatterie (Jerman). Pada umumnya semua bahasabahasa itu mempunyai satu arti yang dituju, yaitu "acumulate" atau accumuleren. Ini semua berarti menim-bun, mengumpulkan atau menyimpan. Me-nurut Daryanto akumulator adalah baterai yang merupakan suatu sumber aliran yang paling populer yang dapat digunakan dimana- mana untuk keperluan yang beranekaragam. 
Menurut Rudolf Michael, aku-mulator dapat diartikan sebagai sel listrik yang berlangsung proses elekrokimia secara bolakbalik (reversible) dengan nilai efisiensi yang tinggi. Disini terjadi proses pengubahan tenaga kimia menjadi tenaga listrik, dan sebaliknya tenaga listrik menjadi tenaga kimia dengan cara regenerasi dari elektroda yang dipakai, yaitu dengan melewatkan arus listrik dengan arah yang berlawanan di dalam sel-sel yang ada dalam akumulator.

Saat pengisian tenaga listrik dari luar diubah menjadi tenaga listrik didalam akumulator dan disimpan didalamnya. Sedangkan saat pengosongan, tenaga di da-lam akumulator diubah lagi menjadi tenaga listrik yang digunakan untuk mencatu energi dari suatu peralatan listrik. Dengan adanya proses tersebut akumulator sering dikenal dengan elemen primer dan sekunder.

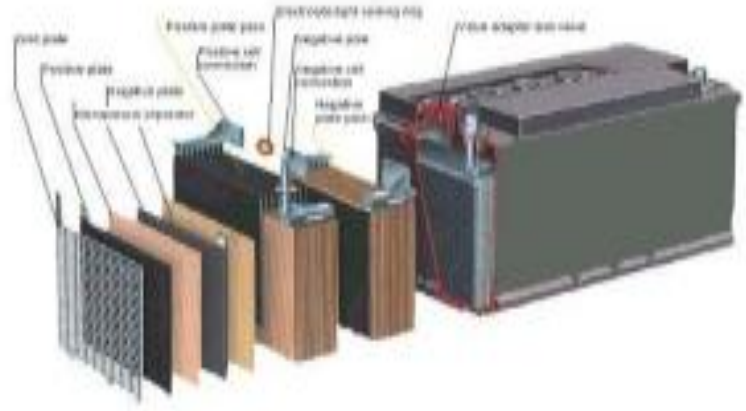

Gambar 7. Baterai dan Elemen-elememnya[3]

\section{Inverter}

Untuk kebutuhan listrik AC, energi listrik yang disimpan di baterai dirubah menjadi listrik AC menggunakan In-verter. Inverter adalah perangkat elektrik yang digunakan untuk mengubah arus listrik searah (DC) menjadi arus listrik bolak balik (AC). Inverter mengkonversi arus DC 12-24 V dari perangkat seperti baterai, panel surya/solar cell menjadi arus AC $220 \mathrm{~V}$.

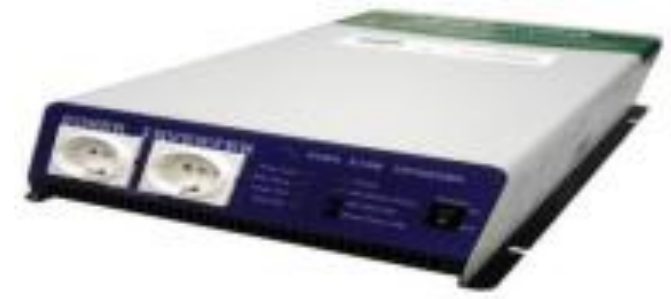

Gambar 8. Inverter[3]

Beberapa hal yang perlu dipertimbangkan dalam pemilihan inverter:
1. Kapasitas beban dalam Watt, usahakan memilih inverter yang beban kerjanya mendekati dengan beban yang hendak kita gunakan agar effisiensi kerjanya maksimal.

2. Input DC $12 \mathrm{~V}$ atau $24 \mathrm{~V}$.

3. Sinewave ataupun square wave outuput AC.

True sine wave inverter diperlukan terutama untuk beban-beban yang masih menggunakan motor agar bekerja lebih mudah, lancar dan tidak cepat panas. Oleh karena itu dari sisi harga maka true sine wave inverter adalah yang paling mahal diantara yang lainnya karena dialah yang paling mendekati bentuk gelombang asli dari jaringan listrik PLN. Sedangkan pada square wave inverter bebanbeban listrik yang menggunakan kumparan/motor tidak dapat bekerja sama sekali.

Rugi-rugi (loss) yang terjadi pada inverter biasanya berupa dissipasi daya dalam bentuk panas. Pada umumnya efisiensi inverter adalah berkisar $50-90 \%$ tergantung dari beban outputnya. Bila beban outputnya semakin mendekati beban kerja inverter yang tertera maka efi-siensinya semakin besar.

\section{Karakteristik Panel Fotovoltaik}

Sifat-sifat listrik dari modul surya biasanya diwakili oleh karakteristik arus tegangannya, yang mana disebut juga kurva IV (lihat gambar 2). Jika sebuah modul surya dihubung singkat $\left(\mathrm{V}_{\text {modul }}=0\right)$, maka arus hubung singkat $\left(\mathrm{I}_{\mathrm{sc}}\right)$ mengalir. Pada keadaan rangkaian terbuka $\left(\mathrm{I}_{\text {modul }}=0\right)$, maka tegangan modul disebut tegangan terbuka $\left(\mathrm{V}_{\mathrm{oc}}\right)$. Daya yang dihasilkan modul surya, adalah sama dengan hasil kali arus dan tegangan yang dihasilkan oleh modul surya.

$$
P=V x
$$

$I$.

dengan :

$\mathrm{P}=$ Daya keluaran modul (Watt)

$\mathrm{V}=$ Tegangan kerja modul (Volt)

$\mathrm{I}=$ Arus kerja modul (Amperee) 


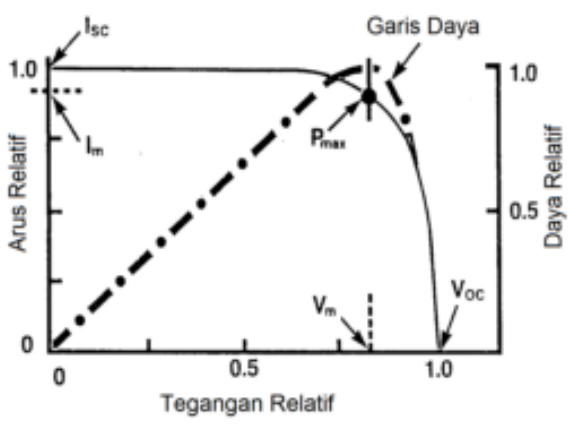

Gambar 9. Kurva Arus-Tegangan dari sebuah modul surya[4]

Tegangan kerja dan arus modul fotovoltaik yang terjadi pada saat daya maksimum (Pmax) tercapai berturut-turut dinyatakan sebagai $\mathrm{Vm}$ dan Im. Apabila pengukuran dilakukan pada radiasi $1000 \mathrm{~W} / \mathrm{m} 2$ dan suhu $25^{\circ} \mathrm{C}$, maka daya mak-simum $(\mathrm{P})$ yang dihasilkan oleh modul disebut pula sebagai daya puncak (peak power) suatu modul fotovoltaik, dan dinyatakan sebagai Ppeak.

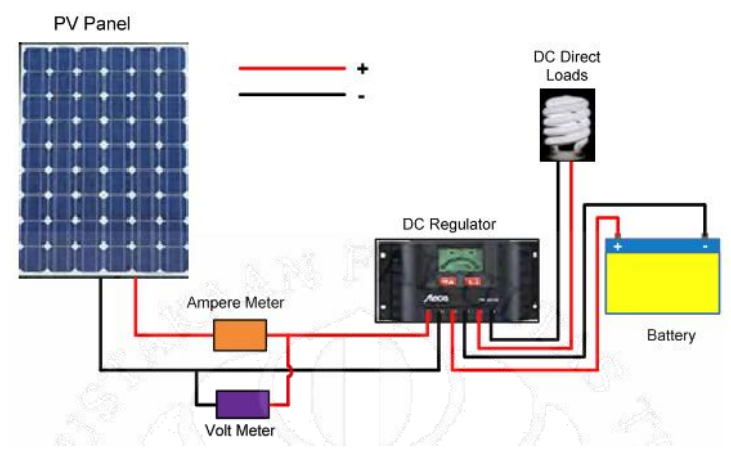

Gambar 10. Gambar Rangkaian PLTS

$\mathrm{P}_{\max }=\mathrm{I}_{\mathrm{m}} \times \mathrm{V}_{\mathrm{m}}$

dengan :

$\mathrm{P}_{\max }=$ Daya maksimum keluaran

modul (Watt)

$\mathrm{V}_{\mathrm{m}}=$ Tegangan kerja modul pada daya maksimum (Volt)

$\mathrm{I}_{\mathrm{m}}=$ Arus kerja modul pada daya maksimum(Amperee)

Catatan: Pada kondisi penyinaran $1000 \mathrm{~W} / \mathrm{m}$ dan temperatur $25^{\circ} \mathrm{C}$, maka Pmax $=\mathrm{P}_{\text {eak }}$

\section{Efisiensi Panel Fotovoltaik}

Efisiensi modul surya berdasarkan uraian diatas jelas berubah terhadap tegangan kerjanya.Karenanya efisiensi modul surya selalu ditetapkan pada daya puncaknya (peak power).Sedangkan daya input dari penyinaran matahari dapat dihitung berdasarkan pengukuran sebagai berikut:

$\mathrm{P}_{\text {input }}=\mathrm{F} \cdot \mathrm{G}_{\mathrm{u}} \cdot \mathrm{A}$

dengan:

$\mathrm{F}=$ faktor kalibrasi pyranometer atau solarimeter $\left(\mathrm{mV} . \mathrm{m}^{2} / \mathrm{Watt}\right)$

$\mathrm{G}_{\mathrm{u}}=$ intesitas matahari terukur $(\mathrm{mV})$

$\mathrm{A}=$ luas efektif dari modul fotovoltaik

$\left(\mathrm{m}^{2}\right)$

Maka efisiensi maksimum dari modul

fotovoltaik dapat dihitung sebagai berikut:

$$
\eta=\frac{P_{\text {output }}}{P_{\text {input }}}=\frac{I_{m} \cdot V_{m}}{f \cdot G_{u} \cdot A}
$$

Pembangkit listrik tenaga surya pada dasarnya adalah pecatu daya (alat yang menyediakan daya), dan dapat dirancang untuk mencatu kebutuhan listrik yang kecil sampai dengan besar, baik secara mandiri, maupun dengan hybrid (dikombinasikan dengan sumber energi lain) baik dengan metode Desentralisasi (satu rumah satu pembangkit) maupun dengan metode Sentralisasi (listrik didistribusikan dengan jaringan kabel).

Pada siang hari modul surya / panel solar cell menerima cahaya matahari yang kemudian diubah menjadi listrik melalui proses photovoltaic. Energi listrik yang dihasilkan oleh modul surya dapat langsung disalurkan ke beban atau disimpan dalam baterai sebelum digunakan ke beban. Dan arus searah DC (direct current) yang dihasilkan dari modul surya yang telah tersimpan dalam baterai sebelum digunakan ke beban terlebih dahulu.

\section{Hasil dan Pembahasan}

Tabel 1 Hasil perhitungan kinerja dengan beban 3 watt

\begin{tabular}{|c|c|c|c|c|c|}
\hline NO & WAKTU & $\mathrm{V}_{\text {in }}$ & $\mathrm{I}_{\text {in }}$ & $\mathrm{V}_{\text {out }}$ & $\mathrm{V}_{\text {out }}$ \\
\hline 1 & 08.00 & 12 & 0,1 & 11 & 0,1 \\
2 & 09.00 & 16 & 2,5 & 14 & 2,3 \\
3 & 10.00 & 17 & 3,5 & 15 & 3,2 \\
4 & 11.00 & 18 & 3,7 & 16 & 4,1 \\
5 & 12.00 & 20 & 4,5 & 18 & 4,2 \\
6 & 13.00 & 17 & 4,3 & 15 & 4,0 \\
7 & 14.00 & 16 & 3,7 & 14 & 3,5 \\
8 & 15.00 & 15 & 3,5 & 13 & 3,0 \\
9 & 16.00 & 13 & 2,4 & 12 & 2,4 \\
10 & 17.00 & 12 & 0,5 & 10 & 0,3 \\
\hline
\end{tabular}


Tabel 2. Hasil Perhitungan Daya

\begin{tabular}{|c|c|c|c|c|}
\hline NO & WAKTU & $\mathrm{P}_{\text {in }}$ & $\mathrm{P}_{\text {out }}$ & $\eta \%$ \\
\hline 1 & 08.00 & 1 & 1 & 92 \\
2 & 09.00 & 40 & 32 & 81 \\
3 & 10.00 & 60 & 48 & 81 \\
4 & 11.00 & 67 & 66 & 98 \\
5 & 12.00 & 90 & 76 & 84 \\
6 & 13.00 & 73 & 60 & 82 \\
7 & 14.00 & 59 & 49 & 83 \\
8 & 15.00 & 53 & 39 & 74 \\
9 & 16.00 & 31 & 29 & 92 \\
10 & 17.00 & 6 & 3 & 50 \\
\hline
\end{tabular}

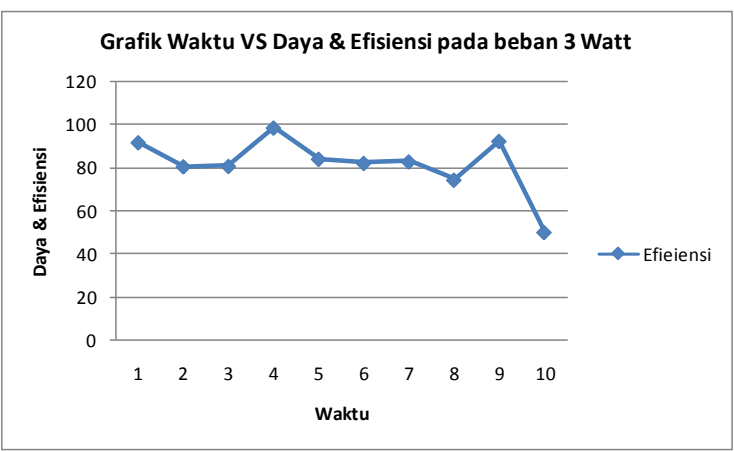

Gambar 11. Grafik Waktu vs Daya dan Efisiensi pada beban 3 Watt

\section{KESIMPULAN DAN SARAN}

\section{Kesimpulan}

Dari hasil penelitian dan hasil perhitungan serta pembahasan maka dapat disimpulkan bahwa beban sangat ber-pengaruh terhadap kinerja solar cell de-ngan kapasitas modul 50 WP. Pada beban 3 watt, 6 watt serta 9 watt, pada beban tersebut semakin besar beban yang dibe-rikan maka semakin kecil kinerja pada solar cell tersebut begitupun sebaliknya. Efisiensi maksimum didapat sebesar efisiensi 98 $\%$ ini terlihat pada beban 3 watt.

\section{DAFTAR PUSTAKA}

[1]. Ikhsan, 2013, Peningkatan Suhu Modul Dan Daya Keluaran Panel Surya Dengan Menggunakan Reflektor, Jurnal ilmiah Dosen pada Jurusan Fisika Fakultas Sains dan Teknologi UIN Alauddin Makassar.

[2]. Solar Cell Panel termuat di http://www.panelsurya.com/index.php/id/s olar-cell. diakses 20 September 2015.

[3] Heri, J, 2011, Pengujian Sistem Pembangkit Listrik Tenaga Surya Solar Cell Kapasitas 50wp, Jurnal Ilmiah.
[4] Sumbung, H. F dan Letsoin, Y, 2012, Analisa dan Estimasi Radiasi Konstan Energi Matahari Melalui Variasi Sudut Panel Fotovoltaik Shs $50 \mathrm{Wp}$, Jurnal Ilmiah Mustek Anim Ha Vol.1 No.1 ISSN: 2089-6697 Program Studi Teknik Elektro Fakultas Teknik Universitas Musamus Merauke.

[5] Cengel, Y. A. (2002). Heat Tasfer a Partical Approach with EES CD, New York : McGraw-Hill Science Engineering.

[6] Gambut, A. (2009). Modul 09

Pengembangan Pembangkit Listrik Tenaga Surya (PLTS)

[7] Jarman, 2014, Peran Sektor

Ketenagalistrikan Dalam Perc-epatan Pembangunan Perekonomi-an Nasional. Seminar Ketenaga-listrikan Percepatan Pembangunan Ketenagalistrikan Untuk Mendu-kung Pertumbuhan Ekonomi. Jakarta.

[8] Nugroho. R. A, Facta. M, dan

Yuningtyastuti, 2010, Memaksi-malkan Daya Keluaran Sel Surya Dengan Menggunakan Cermin Pemantul Sinar Matahari, Jurnal Jurusan Teknik Elektro, Univer-sitas Diponegoro Semarang.

[9] Outlook Energi Indonesoa (OEI), 2014. pusat teknologi pengembangan sumberdaya Energi, Jakarta

[10] Simatupang. S, Susilo. B , Hermanto M. B, 2013, Rancang Bangun dan Uji Coba Solar Tracker pada Panel Surya Berbasis Mikrokontroler ATMega16, Jurnal Ilmiah Jurusan Keteknikan Pertanian - Fakultas Teknologi Pertanian - Universitas Brawijaya.

[11] Sunaryo, dan Setiono.J, 2014, Analisis Daya Listrik Yang Dihasilkan Panel Surya Ukuran $216 \mathrm{Cm}$ X $121 \mathrm{Cm}$ Berdasarkan Intensitas Cahaya, Jurnal Ilmiah ISSN: 2339-028X Jurusan Teknik Mesin, Fakultas Teknik, Universitas Muhammadiyah Riau.

[12] Wikipedia, Radiasi Matahari, termuat di http://id.wikipedia.org/wiki/Radiasi_Mata hari diakses 20 September 2015.

[13] Zuhal. 1992. Dasar Teknik Tenaga Listrik dan Elektronika Daya. PT Gramedia Pustaka Utama. Jakarta. 